\title{
Expression of Mucin Synthesis and Secretion in Human Tracheobronchial Epithelial Cells Grown in Culture
}

\author{
Reen Wu, Walter R. Martin, Cynthia B. Robinson, Judith A. St. George, Charles G. Plopper, \\ Geoffrey Kurland, Jerold A. Last, Carroll E. Cross, Ruth J. McDonald, and Richard Boucher \\ California Primate Research Center; Department of Anatomy, School of Veterinary Medicine; \\ Department of Internal Medicine, School of Medicine; and Department of Pediatrics, School of Medicine, \\ University of California, Davis, California; and Department of Medicine, School of Medicine, \\ University of North Carolina, Chapel Hill, North Carolina
}

\begin{abstract}
The effects of culture conditions on growth and differentiation of human tracheobronchial epithelial (HTBE) cells have been defined. Epithelial cells were dissociated from tissues by protease treatment and were plated on tissue culture dishes in F12 medium supplemented with insulin, transferrin, epidermal growth factor, hydrocortisone, cholera toxin, bovine hypothalamus extract, and retinol. HTBE cells did not express any mucociliary function (ciliogenesis or mucin secretion) on tissue culture plastic, but they could be passaged 3 to 5 times with a total of 10 to 25 population doublings. Cells from early passages re-express both these functions when transplanted to tracheal grafts. When tissue culture plates were coated with collagen film or collagen gel substrata, cell attachment and proliferation were stimulated. However, the expression of mucous cell function in culture occurred only when cells were plated on collagen gel substrata and vitamin A (retinol) was present in the medium. Mucous cell differentiation under optimal conditions was defined by ultrastructural studies, by immunologic studies with mucin-specific monoclonal antibodies, and by carbohydrate and amino acid compositional analyses of mucin-like glycoproteins purified from culture medium. These results demonstrate for the first time that HTBE cells can express mucin synthesis and secretion under appropriate culture conditions.
\end{abstract}

The mucus of respiratory tract epithelium plays a very essential role in pulmonary defense by trapping inhaled particles and microorganisms, which are then removed by the mucociliary system (1). The major components responsible for the viscoelastic properties of mucus are large-molecularweight mucous glycoproteins, called mucins $(2,3)$. The mechanisms for regulation of mucin synthesis and secretion in airways are not well understood. Aberrant secretion and accumulation of mucus in the airway lumen is freqeuntly associated with airway diseases. An increased understanding of the nature of the control of mucus secretion under normal steady-state conditions will shed light upon the abnormal secretion of mucus in disease states.

The distribution of cell types responsible for mucus

(Received in original form February 20, 1990 and in revised form May 24, 1990)

Address correspondence to: Reen Wu, Ph.D., California Primate Research Center, University of California, Davis, CA 95616.

Dr. Kurland's current address is: Department of Pediatrics, University of Pittsburgh, Pittsburgh, PA.

Abbreviations: coated with a thin collagen film (collage-coated), CC; collagen gel, CG; epidermal growth factor, EGF; enzyme-linked immunosorbent assay, ELISA; human tracheobronchial epithelial, HTBE; minimal essential medium, MEM; phosphate-buffered saline, PBS; sodium dodecyl sulfate-polyacrylamide gel electrophoresis, SDS-PAGE; void volume, Vo.

Am. J. Respir. Cell Mol. Biol. Vol. 3. pp. 467-478, 1990 secretory activity varies among different animal species and is also quite heterogeneous throughout the epithelium of the conducting airway tree of any species. For instance, the major secretory cell type in the distal intrapulmonary airways is the Clara cell $(4,5)$, whereas in the case of the proximal airways (trachea and bronchi), other secretory cell types, e.g., serous and goblet cells, are found $(6,7)$. Immunocytochemical analyses reveal that most of the secretory granules in these presumptive secretory cells share a similar immunologic determinant, which is characterized by monoclonal antibodies specific for mucin $(8,9)$. It is one of our aims to elucidate the nature of these differentiated cell types and the control of regulation of their expression of these differentiated phenotypes.

To achieve these aims requires an in vitro cell culture system to initiate studies that ultimately define the processes responsible for these regional differences in the epithelial layer, and the control of these differences among different airway generations and between different species. For the upper respiratory tract, such as the tracheal and nasal region, epithelial cell culture systems have been developed $(10,11)$; however, the culture conditions were not optimized for differentiation of mucus-secreting cells. In our laboratory, we have developed a serum-free F12 medium supplemented with insulin, transferrin, epidermal growth factor, hydrocortisone, cholera toxin, and bovine hypothalamus extract for 
in vitro growth of epithelial cells from animal tracheas and human nasal polyps (10). This serum-free culture medium allows us not only to overcome the analytic problems resulting from the relative scarcity of airway cells in vivo by expanding the cell population but also to investigate the cellular basis of defects in diseases and to define the control of cellular differentiation in a well-defined environment. Yankaskas and colleagues were able to use this culture system to mimic the in vivo defect in chloride transport in cystic fibrosis cells (12). In hamster cells, we have been able to control tracheal cell differentiation simply by adding or removing retinoid (13) from the medium, a distinct advantage over the laborious radiation process that must be used to inactivate the retinoid components in various culture media supplemented with serum.

These earlier results indicate that it is possible to express various differentiated functions of airway epithelium in culture. In this report, we focus on the growth and differentiation of mucus secretory function in human tracheobronchial epithelial (HTBE) cells in this defined culture system. Results demonstrate that protease-dissociated HTBE cells can be cultivated over extended periods of time in culture, and that the differentiated function of mucous cells can be expressed and regulated in culture.

\section{Materials and Methods}

\section{Source of Bronchial Tissues}

More than 50 specimens have been obtained thus far from patients undergoing surgery for bronchial obstruction or from autopsy specimens excised within $24 \mathrm{~h}$ after death. All procedures were approved by the University of North Carolina and the University of California, Davis committees on the Protection of the Rights of Human Subjects. These tissues were immersed in minimal essential medium (MEM) and were transported immediately on ice to the laboratory.

\section{Cell Isolation}

Tissues were washed 3 to 5 times with MEM, then treated overnight (14 to $24 \mathrm{~h}$ ) at cold with $0.1 \%$ protease (type 14; Sigma Chemical Co., St. Louis, MO) prepared in MEM. Epithelial cells were isolated from these protease-digested tissues according to the protocol developed in our laboratory for human nasal and various animal tracheal tissues (10). The yield of the protease isolation procedure was normally 1 to $5 \times 10^{5}$ cells $/ \mathrm{cm}^{3}$ of excised tissue. Cell viability (trypan blue dye exclusion) was greater than $90 \%$. More epithelial cells could be obtained from these tissues after a second protease treatment under identical conditions to those described above. The cell yield from the second isolation was 50 to $100 \%$ of the first one, and cell viability was greater than $80 \%$. A third protease treatment was of little further value, since the yield and viability of the resultant cells were much reduced, to 10 to $30 \%$ of the values obtained from the first isolation.

\section{Culture Conditions and Subcultures}

Dissociated cells were plated on tissue culture dishes (Falcon or Corning equilibrated types) at a density of 1 to $5 \times 10^{3}$ cells $/ \mathrm{cm}^{2}$. Some dishes were coated with a thin collagen film (referred to as collagen-coated [CC]) or with collagen gel (CG). The CC dishes were prepared by pipetting a commercial collagen solution (Vitrogen-100 ${ }^{\mathrm{ru}}$; Collagen Corporation, Palo Alto, CA) onto the plastic surface at a concentration of $30 \mu \mathrm{g} / \mathrm{cm}^{2}$ of collagen and air-dried. To prepare CG substrata in a culture dish, a mixture of $5 \times$ MEM (containing $75 \mathrm{mM}$ Hepes, pH 7.2), $1.0 \mathrm{M} \mathrm{NaOH}$, and Vitrogen100 was prepared on ice at a volume ratio of $0.14: 0.06: 0.8$, respectively. Each $35-\mathrm{mm}$ tissue culture dish was coated with this neutralized collagen mixture. After transfer of these dishes to a $37^{\circ} \mathrm{C} \mathrm{CO}_{2}$ incubator, the mixture formed a gel (collagen fibrils) within $30 \mathrm{~min}$. The final concentration by weight of CG was $0.24 \%$. Culture dishes were incubated at $37^{\circ} \mathrm{C}$ with $5 \% \mathrm{CO}_{2}$ in air. The medium was changed every other day, and a final cell density of 3 to $8 \times 10^{4}$ cells $/ \mathrm{cm}^{2}$ was obtained for primary cultures within 7 to $9 \mathrm{~d}$ of incubation.

Cells in primary culture could be further passaged. At least three passages have been obtained for all of the tissues cultured. More passages could be performed in cultures derived from tissues of younger patients. Subcultures were performed as follows: near-confluent cultures were treated with trypsin (0.1\%)-EDTA (1 mM) in phosphate-buffered saline (PBS), pH 7.0. After cells were detached from the plastic surface, an equal volume of trypsin inhibitor solution $(1 \mathrm{mg} /$ $\mathrm{ml}$ ) in F12 medium was added to stop the trypsinization. Cells were recovered by centrifugation and were resuspended in culture medium for plating.

Culture media, F12, and MEM were prepared according to the manufacturer's suggestion and were supplemented with penicillin and streptomycin, garamycin $(50 \mu \mathrm{g} / \mathrm{ml})$, and Hepes ( $15 \mathrm{mM}, \mathrm{pH} 7.2)$. Hormones and growth factors were prepared in $\times 500$ or $\times 1,000$ stocks as described previously (10). Retinoids (retinol, retinal, and retinoic acid) were dissolved in dimethylsulfoxide at $0.01 \mathrm{M}$ and were stored in liquid $\mathrm{N}_{2}$ until used. They were added to media under reduced light conditions to protect against photoinactivation.

\section{Repopulation of Cultured Cells in "Denuded" Tracheal Grafts}

"Denuded" tracheal grafts were prepared from rat according to the protocol described by Terzaghi and associates (18). Briefly, rat tracheal grafts were frozen and thawed twice in liquid $\mathbf{N}_{2}$, then the lumens of tracheas were flushed with MEM. This process kills most of the cells and denudes the epithelium from the lumen. The denuded tracheal grafts were stored in MEM at cold until use. The lumens of tracheal grafts were filled with cultured HTBE cells that were harvested as described above and resuspended in the F12 medium at 1 to 2 million cells $/ \mathrm{ml}$. These grafts were then transplanted subcutaneously in nude mice. In the control, the lumen was not filled with cultured cells. After $1 \mathrm{mo}$, transplanted tracheal grafts were removed from animals and fixed for histochemical staining (hematoxylin and eosin stain).

\section{Immunologic Studies of Mucin Synthesis}

Monoclonal antibodies specific for mucous granules of human or monkey conducting airway epithelium were used to identify mucous cell populations and to quantitate the amount of mucin produced in culture. These antibodies were developed using secretory mucin as immunogen. The 
specificity of these antibodies was characterized by an immunocytochemical method and by Western blot analysis (8). The immunocytochemical study demonstrated that these antibodies recognize the mucous granules of human airway epithelium. Biochemical analysis showed that two of these antibodies (17B1 and 17Q2) recognize high-molecular-weight mucous glycoproteins and that the sensitivity of assay is not affected by the presence of various proteoglycans or by different blood group antigens (14).

Antibodies were used for immunocytochemical identification of mucous cells in culture and for the enzymelinked immunosorbent assay (ELISA) quantification of mucin produced. Cultured cells were either fixed directly with cold methanol, or were first trypsinized and cytospun on a glass slide, then fixed. These fixed cells were treated with an isotonic solution (e.g., PBS) containing 5\% fetal bovine serum to block any nonspecific binding, then reacted with the primary antibody or pre-immune mouse serum (1:1,000 diluted). After $1 \mathrm{~h}$ of incubation at $37^{\circ} \mathrm{C}$, cells were treated with a fluorescein-conjugated secondary antibody: goat antimouse IgG. The stained cells were examined under a fluorescent microscope. A sandwich-type ELISA method was developed for the quantitation of mucin secretion in culture (14). The reference mucin was purified from human sputum by an established method (14). The purity of mucin isolated from sputum and culture media was assessed by compositional analysis of amino acid and carbohydrate by gel filtration and by sodium dodecyl sulfate-polyacrylamide gel electrophoresis (SDS-PAGE). The sensitivity of the ELISA method was linear with respect to mucin concentration between a protein content of 0.2 to $4 \mathrm{ng}$ of mucin per assay.

Monoclonal antibodies were also used to precipitate mucin present in the culture medium. Immunoprecipitation was performed in the presence of $1 \mu \mathrm{g} / \mathrm{ml}$ of purified 17B1 or 17Q2 IgG, $1 \%$ rabbit anti-mouse IgG serum, and 10\% immunoprecipitin (protein A). After several washes (3 to 5 times) with PBS, the precipitate was dissolved in SDSsample buffer (15) containing 3\% SDS and 5\% $\beta$-mercaptoethanol and analyzed by chromatography on a Sepharose CL-2B column.

\section{Biochemical Analyses of Mucin Secreted in Culture}

Mucin was isolated from the culture medium by gel filtration followed by hyaluronidase treatment (13). Briefly, pooled conditioned medium, collected from primary cultures on days 7 to 14 , was denatured with SDS (3\%) and $\beta$-mercaptoethanol $(5 \%)$. Mucin-like glycoproteins were chromatographed on a Sepharose CL-2B column. The elution buffer was a PBS-based solution containing $0.1 \%$ SDS and $1 \%$ $\beta$-mercaptoethanol. The void volume (Vo) fractions were collected and dialyzed against distilled water. In a previous study, we showed that hyaluronate is one of the major contaminants in the Vo preparation. Therefore, the isolated Vo materials were treated with hyaluronidase $\left(10 \mathrm{U} / \mathrm{ml}, 37^{\circ} \mathrm{C}\right.$, $24 \mathrm{~h}$, at $\mathrm{pH} 6.0$ ). The digested sample was then fractionated on a Sepharose CL-2B column. The residing Vo fractions were used for compositional analysis. This purification method has been used to prepare mucin from human sputum and the extent of purification was comparable to other methods based on the results of the compositional analyses.

To confirm that the purified material was mucin-like, a high-performance liquid chromatography (HPLC) method was used to separate sugars and their reduction products (13). Purified mucin after $\beta$-elimination $(0.05 \mathrm{M} \mathrm{NaOH}$ and $1 \mathrm{M} \mathrm{NaBH}_{4}$ ) (16) was hydrolyzed in $4 \mathrm{~N} \mathrm{HCl}$ at $110^{\circ} \mathrm{C}$ for $24 \mathrm{~h}$. The hydrolysate after neutralization was directly chromatographed on an Aminex A-9 column according to the method described previously (13). If the purified glycoprotein was mucin-like, the reduction product of the $O$-linked sugar, galactosaminitol, should be in the resulting hydrolysate.

\section{Sources of Chemicals}

Media, F12, and MEM were from GIBCO (Grand Island, NY). Insulin, transferrin, hydrocortisone, cholera toxin, protease (type 14), alkaline phosphatase, all-trans-retinoic acid, -retinal, and -retinol were purchased from Sigma. Epidermal growth factor (EGF) was obtained from Upstate Biotechnology (Lake Placid, NY). [ $\left.{ }^{3} \mathrm{H}\right]$ glucosamine and $\left[{ }^{3} \mathrm{H}\right]$ serine were products of ICN (Irvine, CA). Vitrogen100 was purchased from Collagen Corp. (Palo Alto, CA). Hepes and hyaluronidase (Streptomyces) were from CalBiochem (San Diego, CA). Vectastain ABC kit and FITC-conjugated goat anti-mouse IgG were obtained from Vector Laboratories (Burlingame, CA). Bovine hypothalamus was obtained from PelFreeze (Pine Bluff, AR). The remaining chemicals used were analytical reagent grade or the highest quality available commercially.

\section{Results}

\section{Growth of Human Tracheobronchial Epithelial} Cells in Culture

We have demonstrated previously that protease-dissociated epithelial cells from human nasal tissues could be cultured in a defined serum-free medium (17). A similar approach was used with the HTBE cells. Except for the problems associated with contamination by microorganisms in culture for certain specimens, we were able to initiate primary epithelial cultures from all of the human tissues received. The morphology of HTBE cells grown on a plastic tissue culture surface in this defined medium is shown in Figure 1. HTBE cells grown on CC or on CG substrata are also shown. Treatment with retinol was essential for cells to continue proliferation on the CG substrata (Figures $1 c$ and $f$ ) but not on other types of substrata. To further define this effect, a growth study as a function of the concentration of retinol and its derivatives, retinal and retinoic acid, was performed. As shown in Figure 2, retinol is more effective than retinal or retinoic acid in supporting HTBE cell growth on CG substrata. Retinoic acid at a concentration of $1 \mu \mathrm{M}$ is toxic to cells, whereas $1 \mu \mathrm{M}$ retinol has no apparent cytotoxicity and a maximum stimulation of growth was observed.

The effects of collagen substrate on cell growth are demonstrated in Figure 3, which shows that cell attachment was dependent on the amount of collagen coated, and reached a maximum value at a collagen concentration of greater than $100 \mu \mathrm{g} / 35-\mathrm{mm}$ dish or near $10 \mu \mathrm{g} / \mathrm{cm}^{2}$ of surface. In an $8-\mathrm{d}$ cell growth study, the cell number was proportional to the amount of collagen coated. By comparison, under the same culture conditions the cell attachment was $59 \%$ and the 8-d growth was 0.95 million cells/dish when CG was used as sub- 

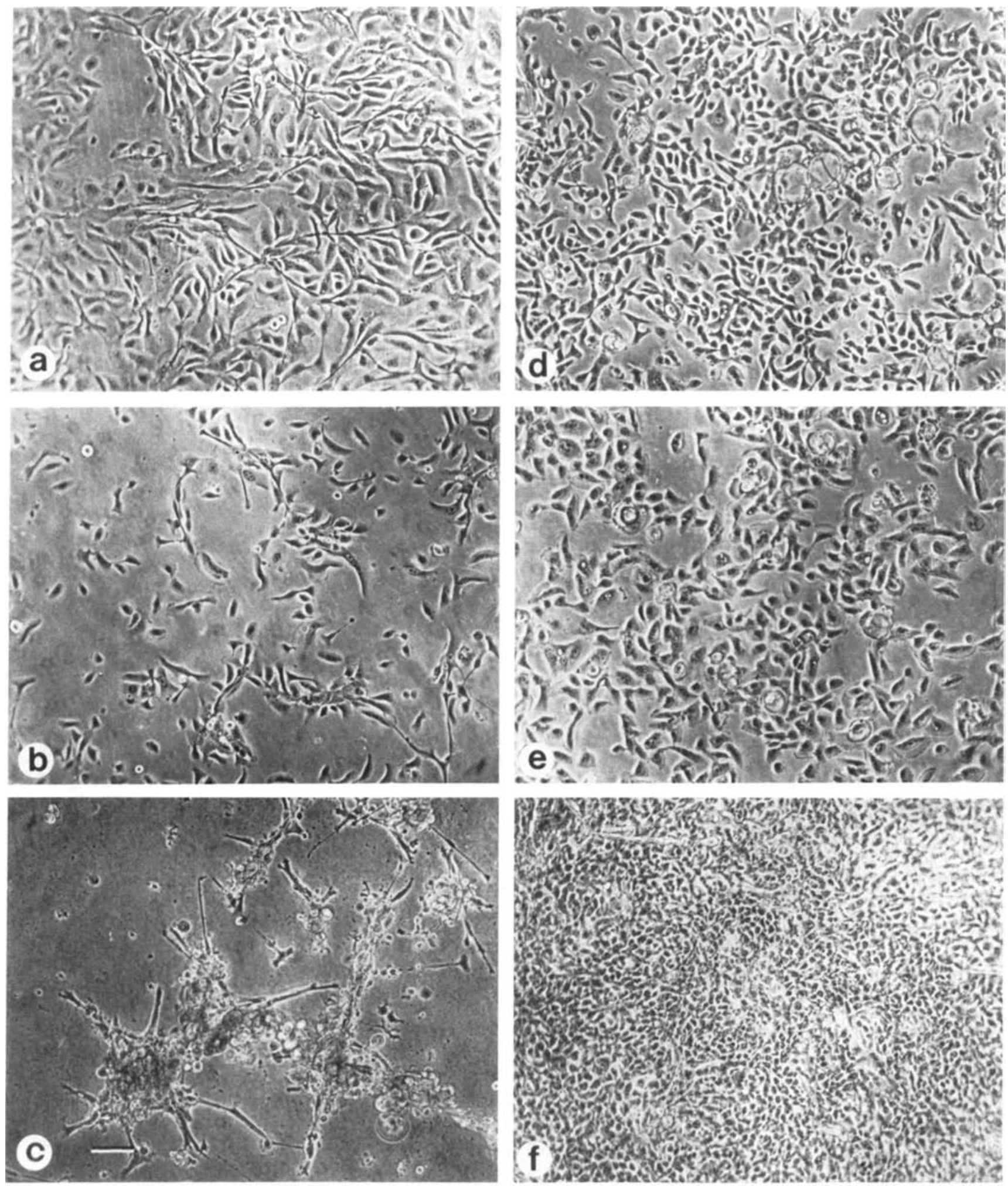

Figure 1. Morphology of HTBE cells in culture as observed under the phase-contrast microscope. HTBE cells were plated on a plastic culture surface ( $a$ and $d$ ) or on a surface coated with $C C$ (b and $e$ ) or with CG ( $c$ and $f$ ) in the defined medium supplemented with (d through f) or without (a through c) retinol as described in the text. Bar $=100 \mu \mathrm{m}$. 


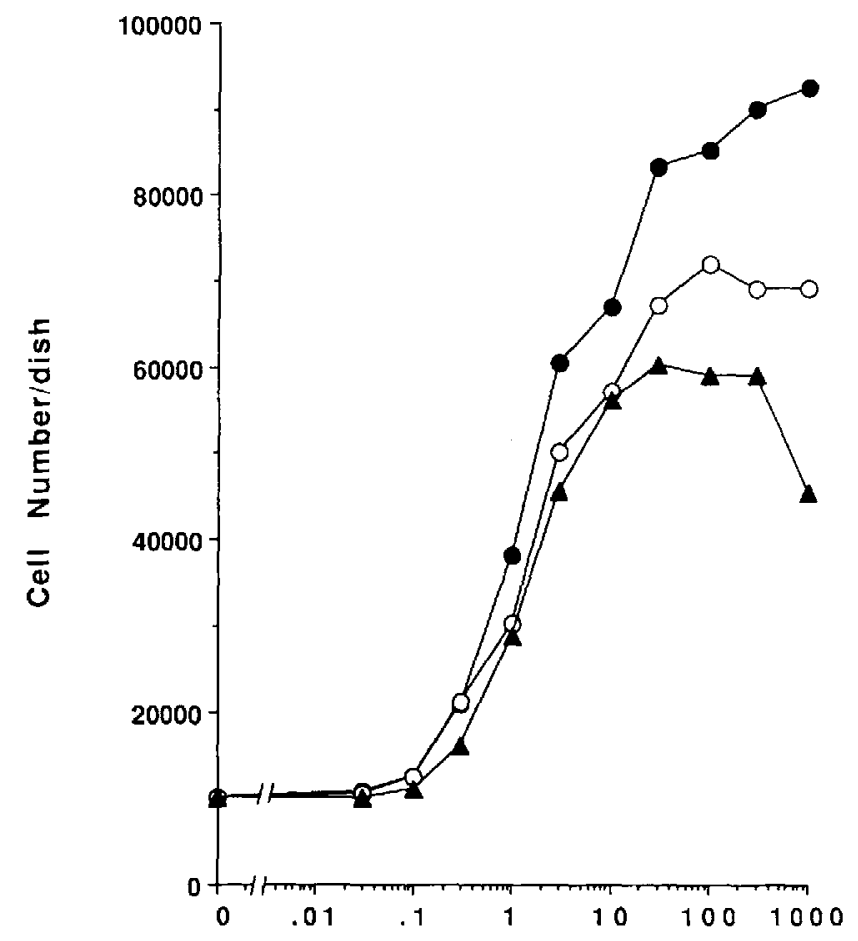

Retinoid ( $\mathrm{nM}$ )

Figure 2. Effects of various concentrations of retinoids in the medium on cell growth. HTBE cells were plated on CG substrata in medium supplemented with various concentrations of retinol (closed circles), retinal (open circles), and retinoic acid (triangles) as indicated. Cell number was determined at day 10 after plating.

stratum. These results suggest maximum cell attachment and growth on CG substratum.

The seven hormonal supplements used in the serum-free medium for this study were chosen based on previous results in developing human nasal and hamster tracheal epithelial cell culture systems $(10,13,17)$. In order to determine whether or not this medium composed of these seven growth supplements was suitable for HTBE cultures, two experiments were performed. As shown in Figure 4, the cell number per dish in a 7-d growth study was decreased in each medium prepared lacking one factor. This result suggests that each of these seven growth supplements has growthstimulating activity. Among them, insulin and EGF were the two most important supplements in supporting HTBE cell growth in vitro because cell growth was consistently inhibited in the absence of either one of them in the culture medium. In the second experiment, we determined whether or not primary adult HTBE cells could be cultivated on a longterm basis and passaged in this serum-free, hormone-supplemented culture medium. Because serum contains inhibitors that would prohibit HTBE cell proliferation, trypsin inhibitor was used rather than serum to stop the trypsinization action during subcultures. By use of this approach, most of the primary HTBE cells maintained on a plastic tissue culture surface were able to be subcultured. An example of such a serial subculture is shown in Figure 5. HTBE cells isolated from an otherwise healthy 21 -yr-old male who died due to an automobile accident were able to be passaged 3 times and reached a cumulative growth of 25 population doublings. However, this proliferative success could not be accomplished with HTBE cells maintained on CG substrata. One of the problems was the difficulty of detaching cells grown on CG substrata. An increase in the amount of EDTA (or EGTA) from $1 \mathrm{mM}$ to $5 \mathrm{mM}$ in the trypsin-EDTA solution helped to detach the cells from the CG; however, the viability of cells at the higher concentration of EDTA (as evaluated by trypan blue exclusion) was greatly reduced. Protease and collagenase have also been tested as cell-detaching agents and did not produce satisfactory results.

\section{Expression of Differential Functions in Culture}

Cells with beating cilia were found in most of the primary cultures. These ciliated cells apparently were part of the primary dissociated HTBE cell population. Under the phasecontrast microscope, we have not observed any obvious increase of the number of ciliated cells throughout the period in primary culture. Therefore, we have focused on the mucous cell population in culture. As shown in Figure 6, the monoclonal antibody $17 \mathrm{Bl}$, which was used previously for tracheal mucin characterization and quantitation (14), stained only the mucous granules of human airway epithelium (Figure 6a). In the control, without the primary antibody, no positive stain was observed (Figure 6b). By using this monoclonal antibody, we were able to observe mucous cell differentiation in cultures maintained on CG substratum (Figure

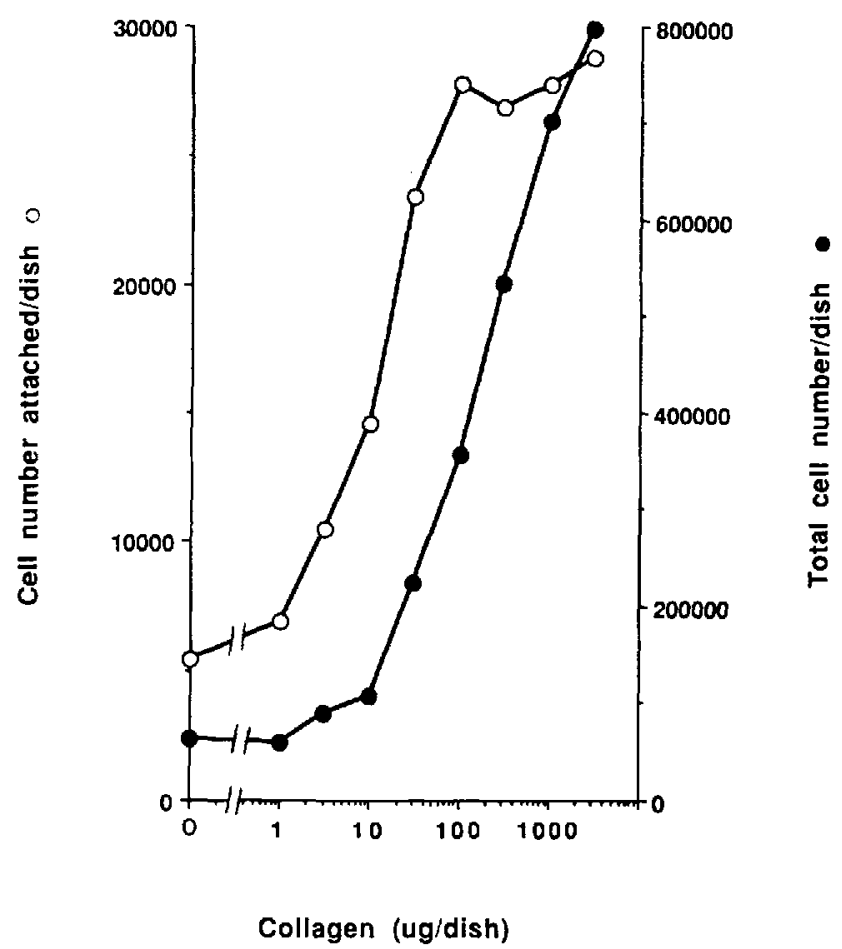

Figure 3. Effects of collagen on cell attachment and growth. HTBE cells were plated on $60-\mathrm{mm}$ plastic bacterial dishes coated with various amounts of collagen as indicated. The seeding density was 5 $\times 10^{4}$ cells/dish. Cell number was determined at day 1 (open circles) and day 8 (closed circles). 

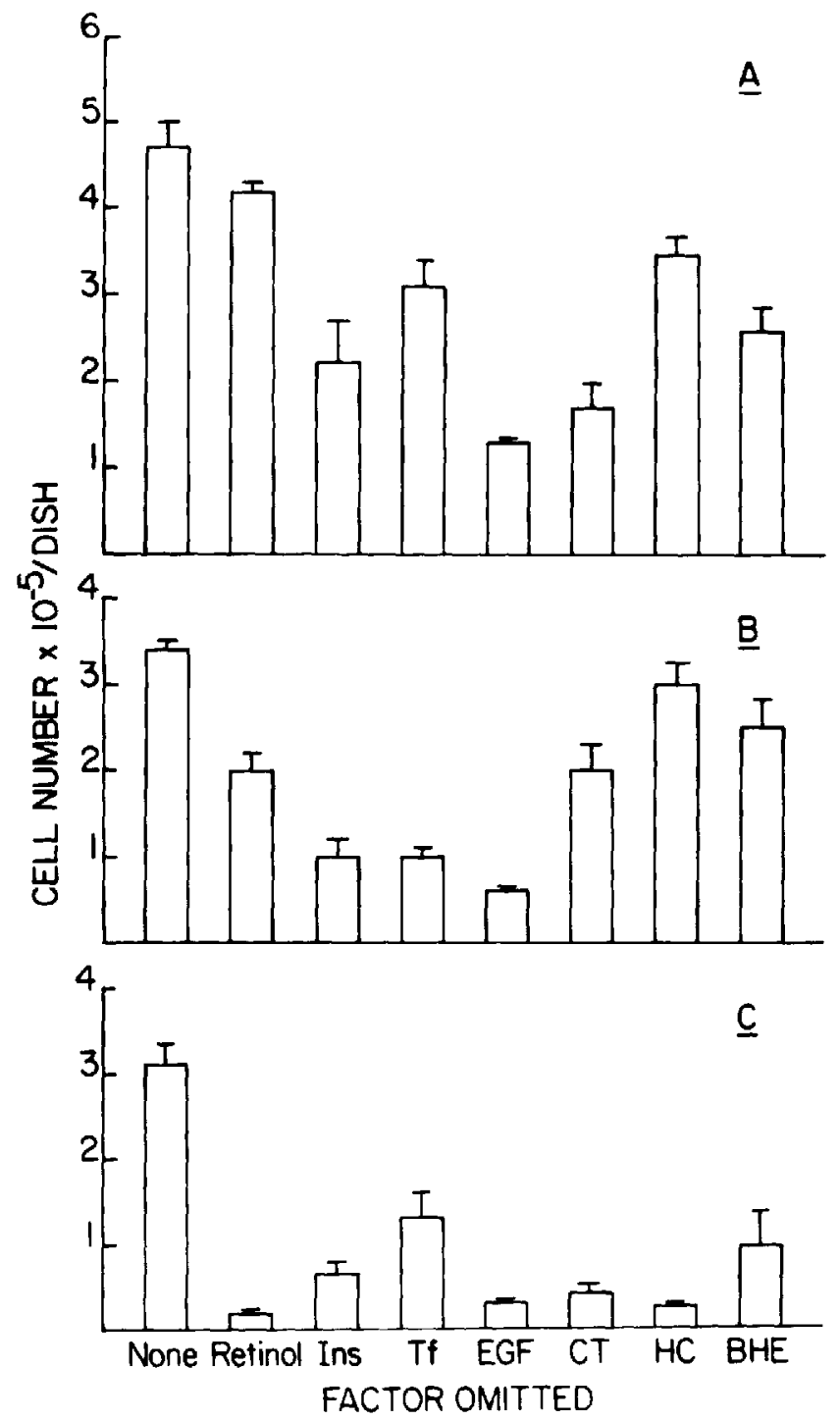

Figure 4. Effect of omission of one of the hormonal supplements on cell growth. HTBE cells were plated on dishes that were untreated (A), or treated with CC (B) or CG (C) in the complete medium supplemented with seven factors or in the complete medium with one of the hormone supplements omitted as indicated. Cell number in each dish was determined at day 7 and results are presented averages of triplicate dishes $(+1 \mathrm{SE})$.

7). A direct staining of cultured cells with antibody could be observed by fluorescence microscopy (Figure 7d). However, quantitative evaluation of the degree of staining is difficult because of the high background due to nonspecific stain uptake in the CG substratum. In order to visualize the staining of cultured cells, these cells were dissociated from the culture substrata and cytospun on glass slides. After fixation of the cells, slides were stained with the antibody. We have observed $30 \%$ of the cells stained positively with the antibody (Figure 7a). At higher magnification, the stain exhibited a granular pattern (Figure $7 \mathrm{c}$ ). The control, without the primary antibody added, was negative (Figure $7 \mathrm{~b}$ ). Similar negative results were obtained for cells not maintained on a CG substratum, whether tissue culture plastic or dried collagen coat was used as substratum.
To further examine mucous cell differentiation in vitro, media conditioned by HTBE cells were analyzed by a double-sandwich ELISA method (14). Conditioned medium of HTBE cells grown on CG assayed at or near confluency reacted with the antibody in a dose-dependent manner (Figure 8). An absorbance of $0.8 \mathrm{U}$ in each microtiter well was equivalent to $5 \mathrm{ng} / \mathrm{ml}$ of sputum mucin. In contrast, medium that was either not conditioned or was conditioned by cells maintained on plastic or dried CC surfaces did not contain mucous glycoconjugates, using an assay that would have detected as little as $0.5 \mathrm{ng} / \mathrm{ml}$ of mucin. Vitamin A was required in the medium of CG cultures in order for them to express the 17Bl-positive antigen.

Consistent with the above observations, cultured cells maintained on CG substrata contained conspicuous granules and lesser amounts of tonofilaments (Figure 9), while cultured cells maintained on plastic tissue culture surfaces were stratified and had numerous dense tonofilaments (data not shown).

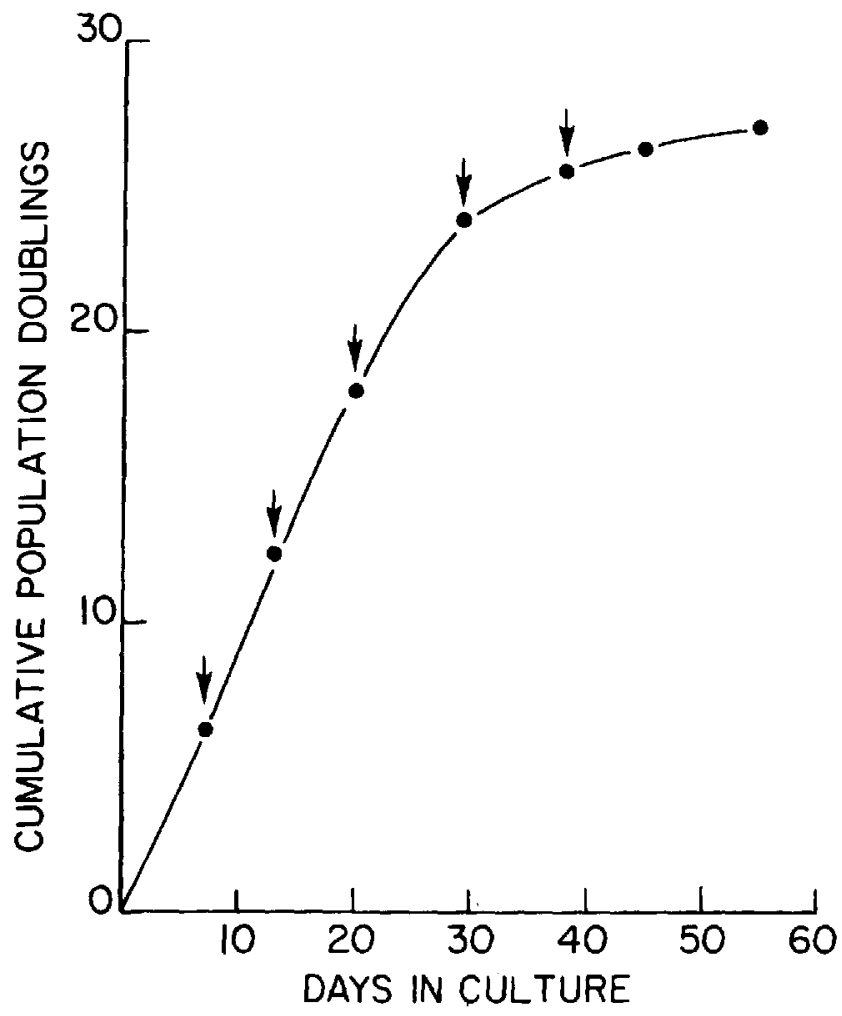

Figure 5. Cumulative population doublings of HTBE cells grown under these defined culture conditions. Primary HTBE cells were plated on tissue culture dishes $\left(1 \times 10^{5}\right.$ cells $/ 60-\mathrm{mm}$ dish $)$ in the hormone-supplemented medium with retinol $(0.1 \mu \mathrm{M})$, as described in the text. The next day, dishes were washed twice with culture medium to remove floating cells and two dishes were used to determine the cell number attached. At day 7, two dishes were used for cell number determination and the rest of the dishes were subcultured to initiate secondary cultures under similar conditions to those used in primary culture. The population doublings were determined as $x$ in the formula: Day 7 number/day 1 number $=$ $2^{x}$. The cumulative population doublings in the secondary and tertiary cultures were determined by the same formula. Arrows indicate the day of subculturing. 

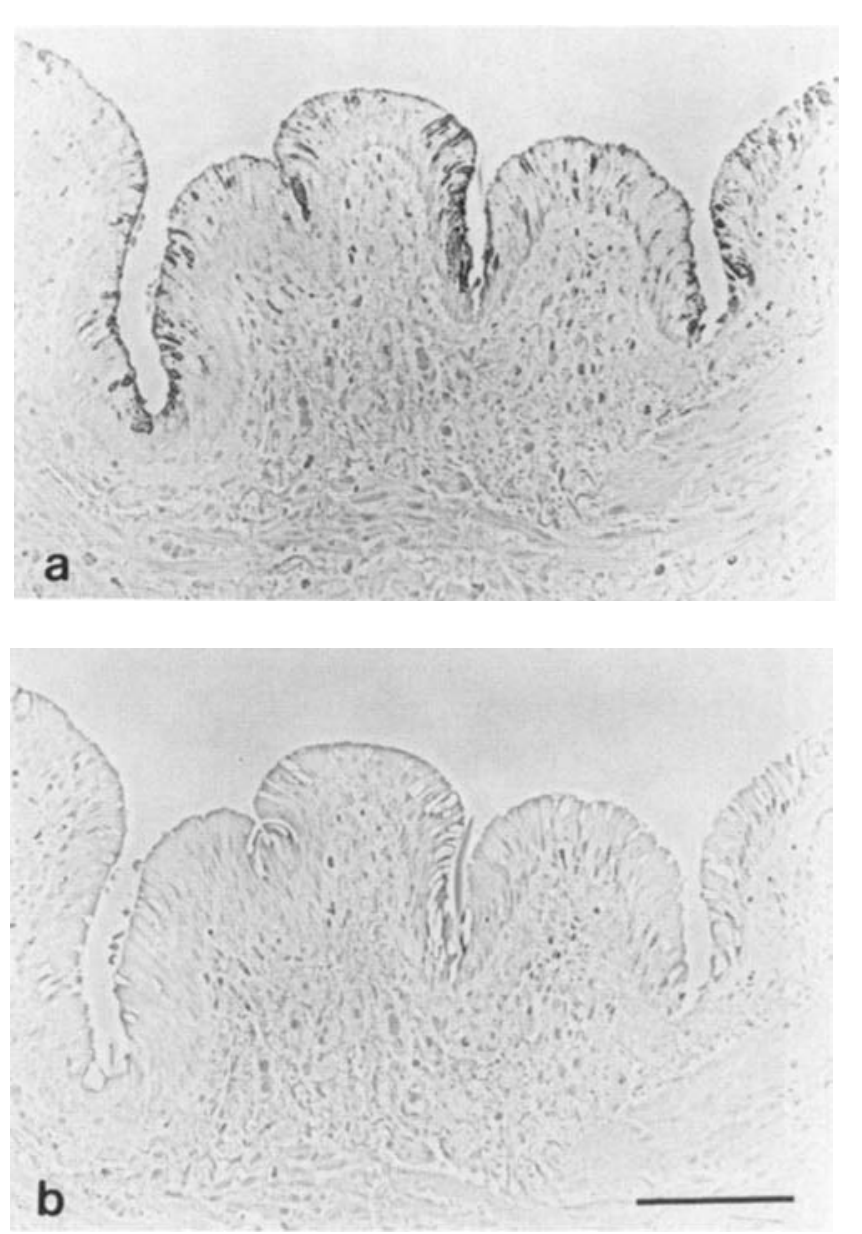

Figure 6. Immunohistochemical staining of human bronchial epithelium with monoclonal antibody 17B1. Methacrylate sections of human bronchial epithelium were stained with $17 \mathrm{~B} 1$ (a) or with the control pre-immune serum (b) by the avidin-biotin peroxidase method, which was supplied by Vector Laboratories in kit form (Vectastain ABC Kit). Positive stains were detected by the Vector stain $\mathrm{ABC}$ Kit.

In order to determine the intrinsic properties of HTBE cells maintained on different substrates, the following two experiments were performed. Primary dissociated cells were plated on tissue culture plastic surfaces at a sparse density. Various and distinctive sizes of colonies were obtained at 7 to $10 \mathrm{~d}$ of incubation. Immunofluorescent staining of these colonies revealed that none of the cells were positively stained by 17B1 antibody. However, when the cells in some of these colonies were passaged onto CG substrata (i.e., in secondary culture), 12 to $35 \%$ of the cells in the secondary culture stained positively with the antibody (data not shown). Controls that were passaged onto plastic surfaces were negative. The second experiment was to determine the intrinsic potential of cultured cells to differentiate in a transplanted tracheal graft, especially those cells that did not express mucous functions in culture. We have shown previously that cultured cells, even in secondary culture, were able to repopulate a denuded tracheal graft and to form a new mucociliary epithelium (10). This result was consistently observed with three separate cultures.
Biochemical Characterization of Mucin Secreted in Culture In order to more fully characterize mucous cell differentiation of the cultured cells, we performed further biochemical studies of the mucin secreted in culture. Cultures were labeled with a radioactive precursor, either $\left[{ }^{3} \mathrm{H}\right]$ glucosamine or $\left[{ }^{3} \mathrm{H}\right]$ serine, and medium was collected after $24 \mathrm{~h}$ of incubation. Analysis of the radioactive medium on a Sepharose CL-2B column showed the incorporation of radioactive precursors into the Vo fractions, as well as into various macromolecules (Figures 10a and 11a). Immunoprecipitation of $\left[{ }^{3} \mathrm{H}\right]$ glucosamine-labeled medium with the mAb $17 \mathrm{Bl}$ demonstrated a specific precipitate, which eluted in the Vo (Figure 10b). Control studies without the primary antibody demonstrated no specific precipitation (Figure 10b). When $\left[{ }^{3} \mathrm{H}\right]$ serine-labeled medium was used in the immunoprecipitation study, multiple peaks were observed (Figure 11b). Control studies demonstrated a similar pattern of precipitation, except for the Vo fraction (Figure 11b). These results indicate that 17B1-precipitable material in the culture medium is a very large molecular weight glycoprotein that can be radiolabeled by both $\left[{ }^{3} \mathrm{H}\right]$ glucosamine and $\left[{ }^{3} \mathrm{H}\right]$ serine.

To further assess the nature of the immunoprecipitate, we have performed enzymatic digestion studies and sugar analyses. The $\left[{ }^{3} \mathrm{H}\right]$ glucosamine-labeled precipitate was resistant to a number of glycosidic enzymes, such as hyaluronidase, chondroitinase, heparitanase, heparanase, and $N$-type glycosidases, such as endoglycosidases A, B, D, F, and $\mathrm{H}$ (data not shown). The precipitate labeled with $\left[{ }^{3} \mathrm{H}\right]$ glucosamine was subjected to $\beta$-elimination and acid hydrolysis, and the resulting hydrolysates were analyzed by HPLC. The retention time of each peak was compared with standards of glucosamine, galactosamine, glucosaminitol, and galactosaminitol (Figure 12). The precipitate after acid hydrolysis contained labeled galactosaminitol, as well as glucosamine and galactosamine.

Based on these results, a preparative protocol was developed for the isolation of mucin from pooled culture medium. Medium was dialyzed and lyophilized, then separated on a Sepharose CL-2B column. Most of the immunospecific peak was in the Vo fractions. These fractions were pooled and further dialyzed and lyophilized. The resultant fraction was treated with hyaluronidase and purified by chromatography on the Sepharose CL-2B column. A Vo peak was obtained (data not shown). This material was used for amino acid compositional analysis. The result was compared with that obtained from sputum mucin. As shown in Table 1, although there were some variations in the composition between these two preparations, the amino acid composition of the mucinlike glycoprotein purified from the conditioned medium of HTBE cultures was consistent with that observed in sputum mucin. In both cases, the glycoprotein is rich in serine and threonine and is low in aromatic amino acids. These results suggest that cultured HTBE cells produce a mucin similar in composition to that found in sputum.

\section{Discussion}

We have examined in culture the life span and differentiated functions of HTBE cells isolated from more than $\mathbf{5 0}$ human tissue samples. We have demonstrated that serial cultivation and long-term maintenance of HTBE cells can be carried out 

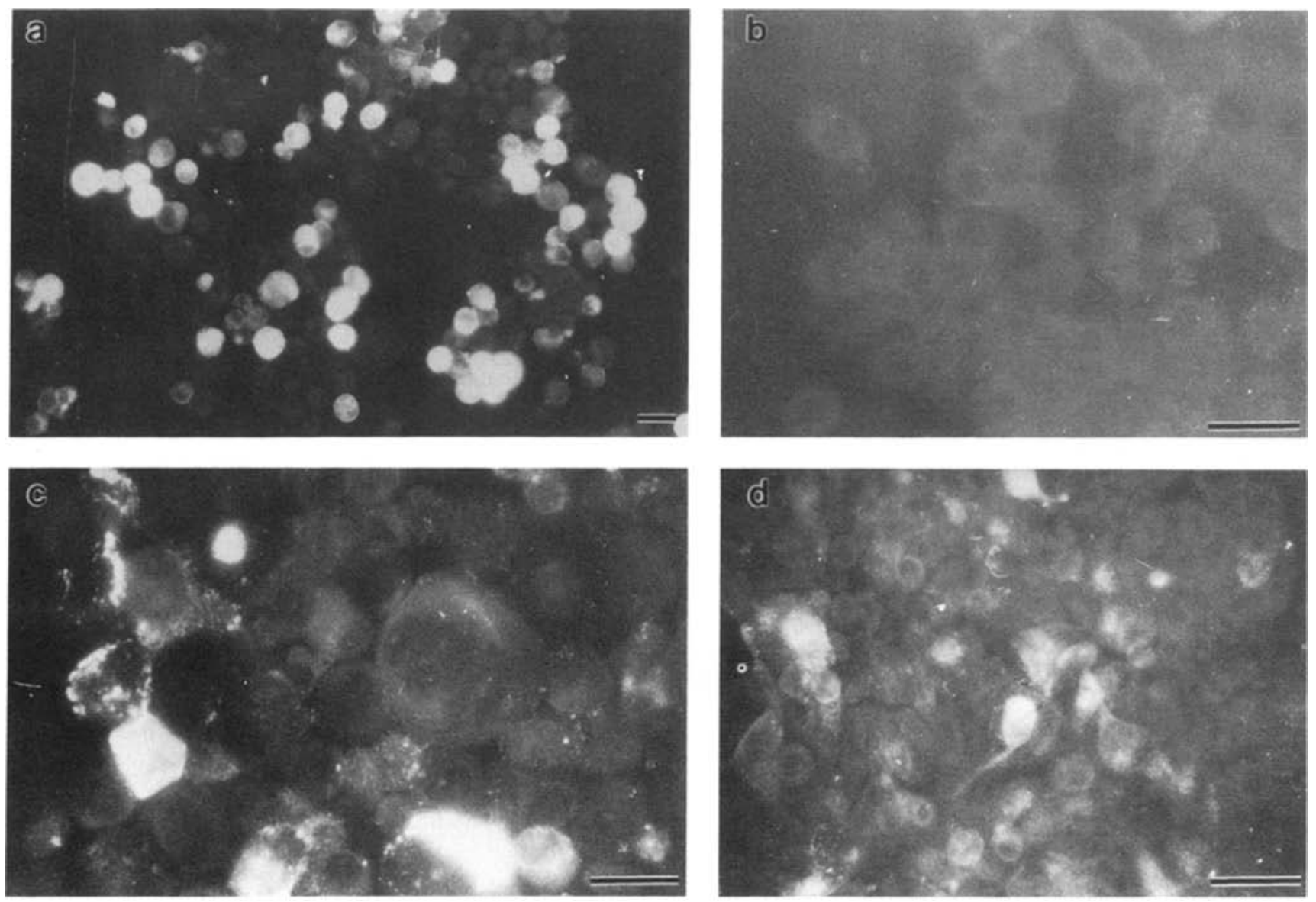

Figure 7. Immunofluorescent staining of cultured cells with the monoclonal antibody 17B1. Cultured HTBE cells, which were maintained on CG (a and c) or on CC (b), were harvested and cytospun on glass slides. Cells fixed with methanol/acetone (1:1) were stained with 17Bl. Cells cultured on CG substrata were also directly stained (d). After reaction with the second antibody, FITC-conjugated goat antimouse IgG, glass slides and dishes were examined under a fluorescent microscope. Panel $c$ is an enlarged picture of panel a, which indicates granulous staining. The control, without the primary antibody added, has a similar negative result as shown in panel $\mathrm{b}$. Bars $=10 \mu \mathrm{m}$.

in a serum-free, hormone-supplemented medium. Collagen substrate, rather than tissue culture plastic, enhances cell attachment and proliferation. However, it is more difficult to serially cultivate primary cultures maintained on collagen substrata than cultures maintained on other surfaces. We have also observed that cells cultured on a noncollagenous substrate neither secreted mucin nor had functional cilia. Instead, squamous cell differentiation was present. However, if these cells were plated on CG substrata, before reaching the terminal stage of squamous cell differentiation, they were capable of expressing mucous secretory function in the secondary culture. They could also repopulate to a new mucociliary epithelium in a transplanted denuded tracheal graft. These results suggest the plasticity of both the cultured cells and the culture system. We have previously shown that tracheal epithelial cells can undergo changes in vitro as mediated by the external environment (20). However, the cultured cells do not lose their intrinsic properties and are able to redifferentiate if appropriate conditions are provided $(18,21$, 22). These observations may justify further studies to optimize culture conditions suitable for epithelial cell differen- tiation. These results show the utility of this cell culture system as a means of expanding human airway epithelial cell populations for various biochemical and physiologic studies and provide a strategy to counteract the relative scarcity of human tissues that limits the number of epithelial cells that can be obtained from airway tissues.

It appears that both vitamin A and a CG substratum are part of the in vitro requirements for HTBE cells to differentiate into a mucociliary epithelium. Although the importance of vitamin $A$ in mucous and ciliated cell differentiation has been well recognized (23-26), the mechanism of this effect remains to be fully characterized. The defined culture system described here will be suitable for elucidating the mechanisms of vitamin A action. In contrast to other reports (11, 27,28 ), we have consistently found that retinol is much better than retinoic acid in supporting growth (Figure 4) of airway epithelial cells in culture. It has been demonstrated in rabbit tracheal epithelial cultures that some, but not all, of the all-trans-retinol inside the cell is oxidized to the retinoic acid forms, such as 13-cis-retinoic acid and all-trans-retinoic acid (29), while no conversion from retinoic acid to retinol 


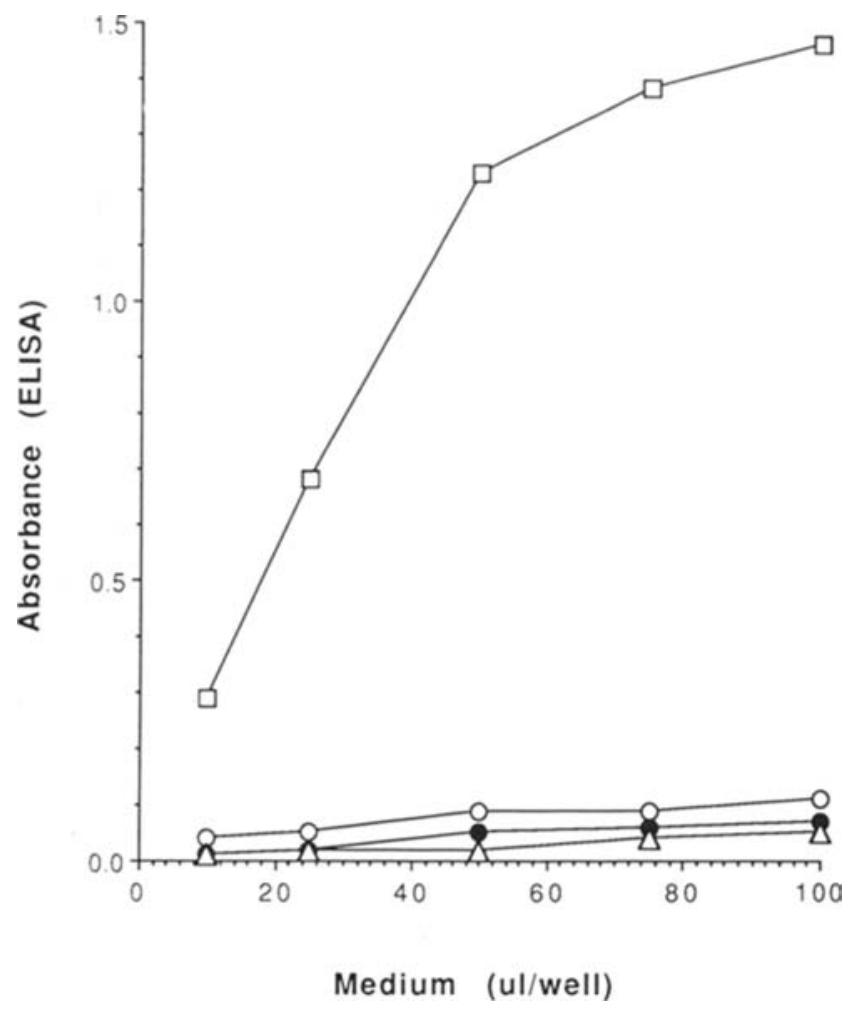

Figure 8. Quantitation of mucin secretion in culture by ELISA. HTBE cells were plated in complete medium supplemented with retinol as described in the text. Conditioned media were collected from HTBE cultures grown on CG (squares), CC (open circles), and plastic (closed circles) at days 12 to 14 of primary cultures. Controls were tested with unconditioned medium (triangles).

should occur because cells do not have the requisite enzyme. The metabolic pathways for various retinoids in human airway epithelial cells have not yet been elucidated. Since we have observed that all analogs of vitamin $A$ are active in supporting growth of HTBE cells on CG, it is possible that retinoic acid is the physiologically active compound in these cells and is formed by these cells after uptake of retinol. However, some of our results do not completely agree with this notion, because the stimulation appears to be inversely related to the case of oxidation of retinoids, in the order retinol $>$ retinal $>$ retinoic acid (Figure 4). An alternative explanation might be that retinol binds to its own receptor, which is different from the retinoic acid receptor (31-34) and is responsible for growth stimulation in HTBE cells. Both retinoic acid and retinal might also bind to this receptor with lower affinity than retinol. However, such a retinol-specific receptor has not been demonstrated. Further work is needed in order to understand the nature of the comparative potency of the various forms of vitamin $A$ in supporting growth and differentiation of cultured airway epithelial cells.

We have also observed that collagen gel (CG) substrata are critical to mucous cell differentiation in vitro, while a thin collagen-coated (CC) substratum was insufficient to induce mucous cell differentiation in vitro. The basis of the different results between $\mathrm{CC}$ surfaces and CG is not clear.
Cell attachment and proliferation were enhanced by $\mathrm{CC}$ in a concentration-dependent manner. Although CG customarily contains more collagen than $\mathrm{CC}$, we have done experiments in which we attempted to use the same amount of collagen in $\mathrm{CC}$ as in the $\mathrm{CG}$ dishes, but even with the same total amount of collagen present, $\mathrm{CC}$ did not support mucous cell differentiation in vitro. Therefore, the difference in expression of mucous cell function between the CC and CG conditions cannot be simply explained by the difference in the amount of collagen in the substrata. Rather, it may be due to the orientation of collagen fibrils in the gel versus in the coated, dried material, or due to the possibility that cells growing three dimensionally into the gels is important for growth and expression of mucous cell function in vitro.

We have previously demonstrated that hamster tracheal epithelial cells plated on CG substrata under culture conditions similar to those described here were able to produce new cilia and mucous granules $(13,19)$. However, only mu-
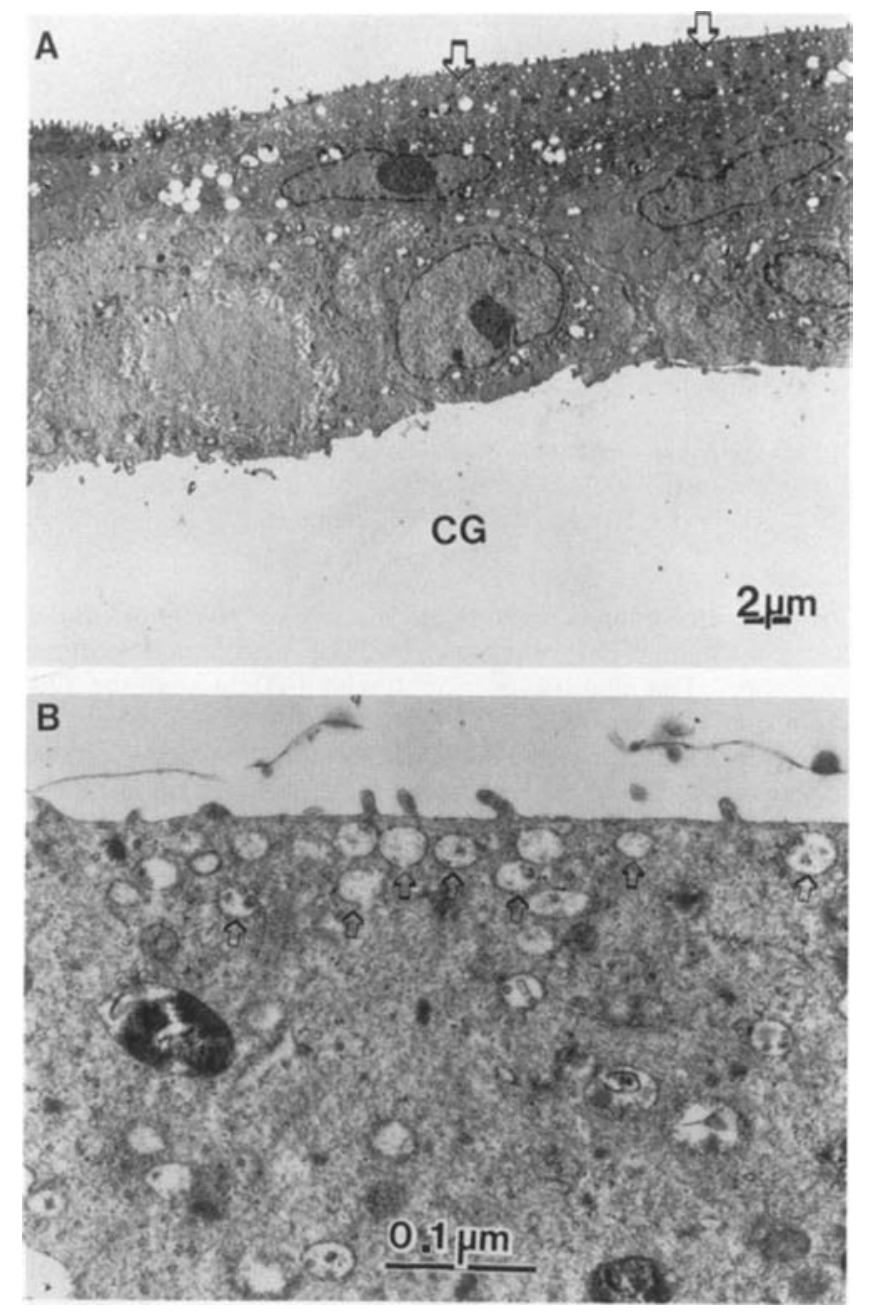

Figure 9. Conspicuous mucous granules in HTBE cells grown on CG in the presence of retinol. Primary HTBE cultures on CG were fixed on day 14 and analyzed ultrastructurally. Conspicuous mucous granules (arrows) in panel A are enlarged and shown in panel B. 

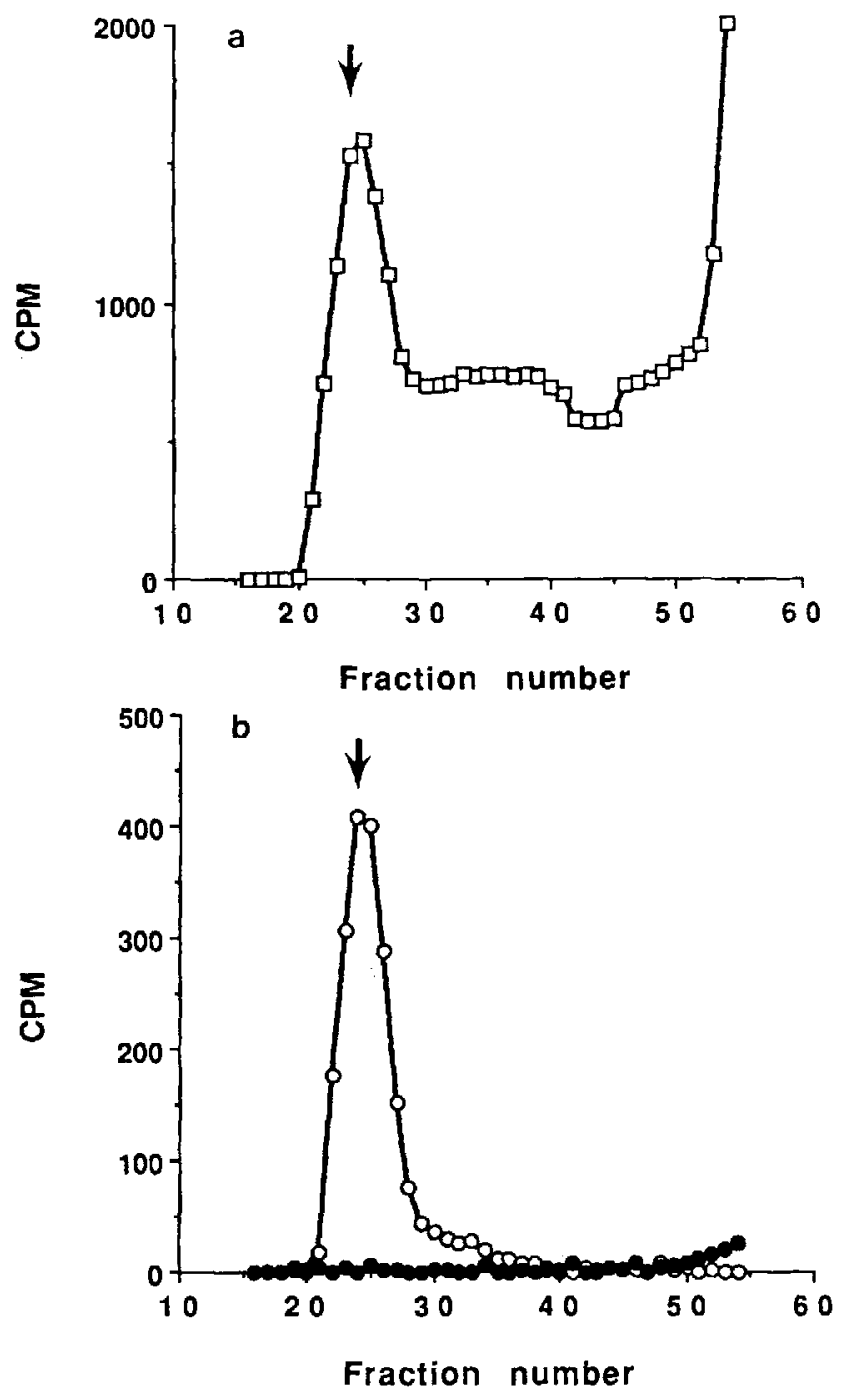

Figure 10. Immunoprecipitation of mucin-like glycoproteins in culture medium. HTBE cells grown on CG in the complete medium were labeled at day 14 overnight with $\left[{ }^{3} \mathrm{H}\right]$ glucosamine (20 $\mu \mathrm{Ci} / \mathrm{ml})$. Media were collected and immunoprecipitated with 17BI as described in the text, and the precipitates were separated on the Sepharose CL-2B column as described. (a) The separation profile of the original medium before immunoprecipitation (squares). (b) Separation profiles of 17B1 (open circles) and control (closed circles) precipitates on the Sepharose CL-2B column. Arrows indicate the void volume fractions.

cous cell differentiation was observed with HTBE cells. The nature of this difference between the cells from different species is not known. Evidence of mucous cell differentiation in the present study included the ultrastructural analysis of conspicuous mucous granules, the immunochemical identification with mucin-specific antibody, and the biochemical characterization of mucin in the culture medium. A central problem for the use of cell culture as a model for airway tissues is how close the secretory products from cell culture systems resemble the compositional and structural analysis, and in the regulation of their synthesis and secretion with in vivo conditions. The mucin-like glycoprotein isolated from the conditioned medium of HTBE cultures revealed similar amino acid composition to the glycoproteins obtained from sputum. Carbohydrate analysis of the mucin-like glycoprotein purified from the conditioned medium has shown that carbohydrate chains were covalently linked by $O$-glycosidic bonds through $N$-acetylgalactosamine to the protein core, a characteristic of mucin-like molecules. Furthermore, both the purified mucin-like glycoprotein and the differentiated cells reacted with monoclonal antibodies specific to mucussecreting granules in vivo and to sputum mucin. These results strongly support the conclusion that HTBE cells under

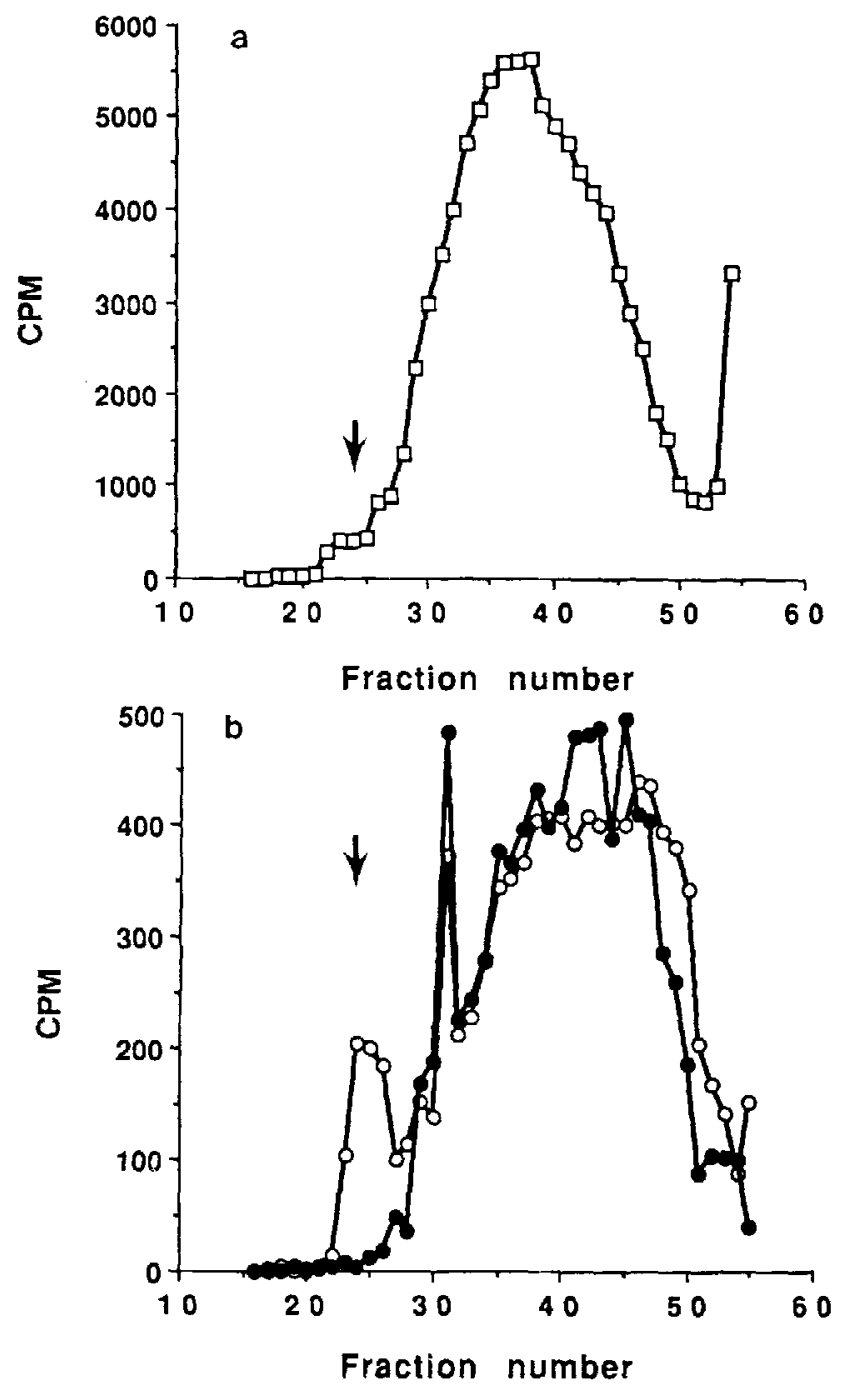

Figure 11. Immunoprecipitation of mucin-like glycoproteins in culture medium. HTBE cells grown on CG in the complete medium were labeled at day 14 overnight with $\left[{ }^{3} \mathrm{H}\right]$ serine $(20 \mu \mathrm{Ci} / \mathrm{ml})$. Media were collected and immunoprecipitated with 17B1 and then analyzed as described in Figure 10. (a) Separation profile of the original medium before immunoprecipitation (squares). (b) Separation profiles of 17B1 (open circles) and control (closed circles) precipitates on the Sepharose CL-2B column. Arrows indicate the void volume fractions. 


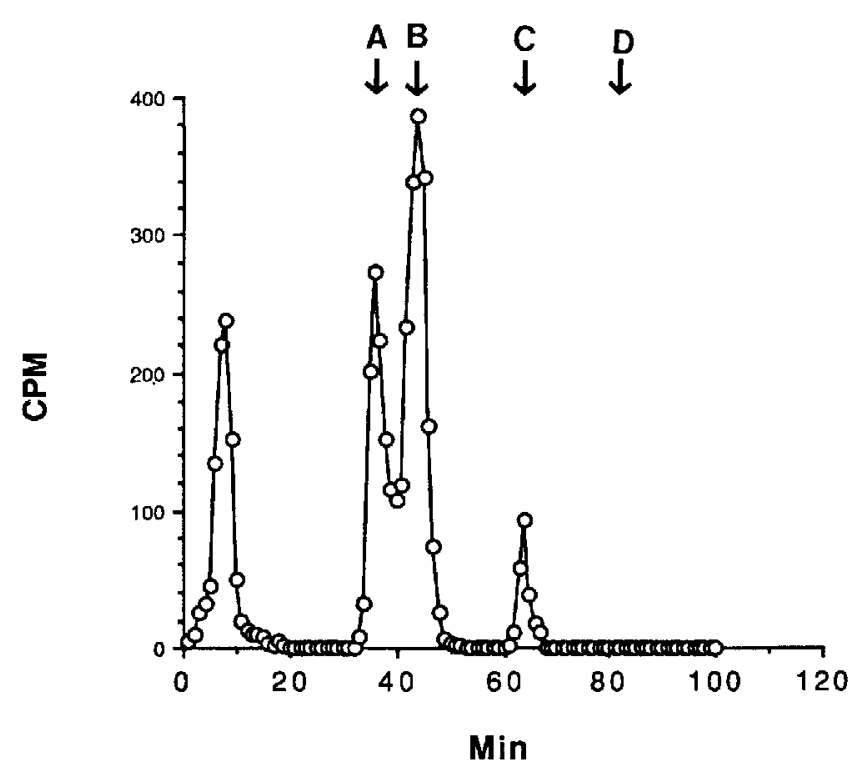

Figure 12. Identification of $\left[{ }^{3} \mathrm{H}\right]$ galactosaminitol on an HPLC column of Aminex A-9. HTBE cells were labeled overnight with [ $\left.{ }^{3} \mathrm{H}\right]$ glucosamine $(100 \mu \mathrm{Ci} / \mathrm{ml})$. Medium was collected and immunoprecipitated by $17 \mathrm{~B} 1$ antibody. The void volume peaks, after extensive dialysis, were subjected to the $\beta$-elimination procedure, followed by acid hydrolysis. Samples were prepared as previously described (13). The markers were: (A) glucosamine; (B) galactosamine; (C) galactosaminitol; and (D) glucosaminitol.

these defined culture conditions are able to secrete authentic mucin.

Lechner and colleagues have also developed a defined cell culture system for long-term cultivation of HTBE cells (11,

TABLE 1

Amino acid composition of mucin-like glycoproteins purified from conditioned medium of HTBE cultures and from sputum

\begin{tabular}{lcr}
\hline Amino Acid* & $\begin{array}{c}\text { Conditioned Medium } \\
\text { (residues/l,000 residues) }^{\dagger}\end{array}$ & Sputum \\
\hline Asp & 73 & 38 \\
Thr & 151 & 237 \\
Ser & 143 & 129 \\
Glu & 80 & 53 \\
Gly & 84 & 107 \\
Ala & 87 & 133 \\
Pro & 95 & 73 \\
Val & 50 & 49 \\
Met & 1 & 3 \\
lle & 41 & 25 \\
Leu & 64 & 49 \\
Tyr & 19 & 11 \\
Phe & 25 & 16 \\
Lys & 38 & 19 \\
His & 10 & 22 \\
Arg & 40 & 35 \\
Cys & ND & ND \\
\hline
\end{tabular}

* Acid hydrolysis $\left(6 \mathrm{~N} \mathrm{HCl}, 100^{\circ} \mathrm{C}\right)$.

$\dagger$ Average from two determinations.

$\ddagger$ ND $=$ not determined.
27). Their medium contains less calcium than is present in Ham's F12 medium $(0.3 \mathrm{mM} \mathrm{Ca})$. Apparently, low calcium concentration helps to prevent epithelial cells from expressing terminal stages of squamous cell differentiation (30). We have confirmed their observation that a lower calcium concentration in the culture medium helps to promote cell proliferation on plastic or on CC substrata. The other major difference in Lechner's system is the use of a different substratum, in which the tissue culture surface is briefly coated with a mixture of fibronectin, collagen, and bovine serum albumin. This treatment apparently enhances cell attachment and cell growth. A similar result can also be achieved with a CC surface as demonstrated here. Although it has been described in Lechner's system that ciliated cells formed in some of the early passage cultures, we were unable to observe a similar result in cultures maintained on a CC surface. In fact, ciliated cells can survive in culture for more than a month. Without quantitative data, it would be difficult to determine whether the ciliated cells observed in Lechner's studies had differentiated in vitro to ciliated cells or were part of the primary isolate.

Acknowledgments: We thank Chris Brown, Vivian Wong, E. Nolan, and Susan Edmondson for their excellent technical assistance in performing many of these studies. We also wish to thank several physicians and nurses from hospitals of the University of North Carolina and the University of California at Davis involved in obtaining the human tissues for these studies. This work was supported in part by grants from the National Institutes of Health (HL-35635, ES-00628, RR-00169), The Cystic Fibrosis Foundation, and the Council for Tobacco Research.

\section{References}

1. Sleigh, M. A., J. R. Blake, and N. Liron. 1988. The propulsion of mucus by cilia. Am. Rev. Respir. Dis. 137:726-741.

2. Roberts, G. P. 1974. Isolation and characterization of glycoproteins from sputum. Int. J. Biochem. 50:265-280.

3. Reid, L., and J. R. Clamp. 1978. The biochemical and histochemical nomenclature of mucus. Br. Med. Bull. 34:5-8.

4. Reid, L., and R. Jones. 1979. Bronchial mucosal cells. Fed. Proc. 38: 191-196.

5. Breeze, R. G., and E. B. Wheeldon. 1977. The cells of the pulmonary airways. Am. Rev. Respir. Dis. 116:705-777.

6. Jeffrey, P. K. 1983. Morphologic features of airway surface epithelial cells and glands. Am. Rev. Respir. Dis. 128:S14-S20.

7. Plopper, C. G. 1983. Comparative morphologic features of bronchiolar epithelial cells: the Clara cells. Am. Rev. Respir. Dis. 128:\$37-S41.

8. St. George, J. A., D. L. Cranz, J. R. Zicker, J. R. Etchison, D. L. Dungworth, and C. G. Plopper. 1985. An immunohistochemical characterization of rhesus monkey respiratory secretions using monoclonal antibodies. Am. Rev. Respir. Dis. 132:556-563.

9. Finkbeiner, W. E., and C. B. Basbaum. 1988. Monoclonal antibodies directed against human airway secretions: localization and characterization of antigens. Am. J. Pathol. 131:290-297.

10. Wu, R. 1986. In vitro differentiation of airway epithelial cells. In In Vitro Models of Respiratory Epithelium. L. J. Schiff, editor. CRC Press, Boca Raton, FL. 1-26.

11. Lechner, J. F., G. D. Stoner, G. H. Yoakum et al. 1986. In vitro carcinogenesis studies with human tracheobronchial tissues and cells. In In Vitro Models of Respiratory Epithelium. L. J. Schiff, editor. CRC Pres Boca Raton, FL. 143-159.

12. Yankaskas, J. R., C. U. Cotton, M. R. Knowles, J. T. Gatzy, and . C. Boucher. 1985. Culture of human nasal epithelial cells on collagen I trix supports: a comparison of bioelectric properties of normal and $c$ stic fibrosis epithelia. Am. Rev. Respir. Dis. 132:1281-1287.

13. Wu, R., E. Nolan, and C. Turner. 1985. Expression of tracheal differentiated functions in serum-free hormone-supplemented medium. J. Cell. Physiol. 125:167-181.

14. Lin, H., D. M. Carlson, J. A. St. George, C. G. Plopper, and R. Wu. 1989. An ELISA method for the quantitation of tracheal mucins from human and nonhuman primates. Am. J. Respir. Cell Mol. Biol. 1:41-48.

15. Laemmli, U. K. 1970 . Cleavage of structural proteins during the assembly of the head of bacteriophage T4. Nature 227:680-685. 
16. Iyer, R. N., and D. M. Carlson. 1971. Alkaline borohydrate degradation of blood group H substance. Arch. Biochem. Biophys. 142:101-105.

17. Wu, R., E. Cheng, J. Yankaskas, M. Knowles, and R. Boucher. 1985 Growth and differentiation of human nasal epithelial cells in culture: serum-free, hormone-supplemented medium and proteoglycan synthesis. Am. Rev. Respir. Dis. 132:311-320.

18. Terzaghi, M., P. Nettesheim, and M. L. Williams. 1978. Repopulation of denuded tracheal grafts with normal preneoplastic epithelial cell populations. Cancer Res. 38:4546-4553.

19. Lee, T. C., R. Wu, A. R. Brody, J. C. Barrett, and P. Nettesheim, 1984 Growth and differentiation of hamster tracheal epithelial cells in culture. Exp. Lung Res. 6:27-45.

20. Wu, R., J. W. Groelke, L. Y. Chang, M. E. Porter, D. Smith, and P. Nettesheim. 1982. Effects of hormones on the multiplication and differentiation of tracheal epithelial cells in culture. In Growth of Cells in Hormonally Defined Media. G. Sirbasku, G. H. Sato, and A. Pardee, editors. Cold Spring Harbor, New York. 641-656.

21. Wu, R., and D. Smith. 1982. Continuous multiplication of rabbit tracheal epithelial cells in a defined hormone-supplemented medium. In Vitro 18:800-812.

22. Chang, L. Y., R. Wu, and P. Nettesheim. 1985. Morphological changes in rat tracheal cells during the adaptive and early growth phase in primary cell culture. J. Cell Sci. 74:283-301

23. Wolback, S. B., and P. R. Howe. 1925. Tissue changes following deprivation of fat-soluble A vitamin. J. Exp. Med. 42:753-777.

24. Sporn, M. B., G. H. Clamon, and M. N. Dunlop. 1975. Activity of vitamin A analogues in cell cultures of mouse epidermis and organ cultures of hamster trachea. Nature 253:47-49.
25. Lotan, R. 1980. Effects of vitamin A and its analogs (retinoids) on normal and neoplastic cells. Biochim. Biophys. Acto 605:33-91.

26. Stahlman, M. T., M. E. Gray, F. Chytil, and H. Sundell. 1988. Effect of retinol on fetal lamb tracheal epithelium, with and without epidermal growth factor: a model for the effect of retinol on the bealing lung of human premature infants. Lab. Invest. 59:25-35.

27. Lechner, J. F., A. Haugen, I. A. McClendon, and E. W. Pettis. 1982. Clonal growth of normal adult human bronchial epithelial cells in a serumfree medium. In Vitro 18:633-642.

28. Jetten, A. M., and H. Smits. 1985. Regulation of differentiation of tracheal epithelial cells by retinoids. In Retinoids, Differentiation and Disease, Ciba Symposium. J. Nugent and S. Clark, editors. Pitman, London. $61-76$.

29. Bhat, P. V., and A. M. Jetten. 1987. Metabolism of all-trans-retinol and all-trans-retinoic acid in rabbit tracheal epithelial cells in culture. Biochim. Biophys. Acta 922:18-27.

30. Hennings, H., D. Michael, C. Cheng, P. Steinert, K. A. Holbrook, and S. H. Yuspa. 1980. Calcium regulation of growth and differentiation of mouse epidermal cells in culture. Cell 19:245-254.

31. Petkovich, M., N. J. Brand, and A. Krust. 1987. A human retinoic acid receptor which belongs to the family of nuclear receptors. Nature 330 : 444-450.

32. Giguere, V., E. S. Ong, and P. Segui. 1987. Identification of a receptor for the morphogen retinoic acid. Narure 330:624-629.

33. Brand, N., M. Petkovich, and A. Krust. 1988. Identification of a second human retinoic acid receptor. Nature 332:850-853.

34. Benbrook, D., E. Lernhardt, and M. Pfahl. 1988. A new retinoic acid receptor identified from a hepatocellular carcinoma. Nature 333:669-672. 